\title{
Retraction: A novel bacterial isolate Stenotrophomonas maltophilia as living factory for synthesis of gold nanoparticles Yogesh Nangia ${ }^{1}$, Nishima Wangoo ${ }^{1}$, Nisha Goyal ${ }^{1}$, G Shekhawat ${ }^{2}$ and C Raman Suri*1
}

Address: ${ }^{1}$ Institute of Microbial Technology (CSIR), Sector 39-A, Chandigarh 160036, India and ${ }^{2}$ Institute of Nanotechnology, Northwestern University, Evanston, IL, USA

Email: Yogesh Nangia - yogesh.nangia@imtech.res.in; Nishima Wangoo - nishima@imtech.res.in; Nisha Goyal - nishagoyal@imtech.res.in; G Shekhawat - g-shekhawat@northwestern.edu; C Raman Suri* - raman@imtech.res.in

* Corresponding author

Published: 15 October 2009

Microbial Cell Factories 2009, 8:52 doi:10.1186/1475-2859-8-52
Received: 13 October 2009

Accepted: 15 October 2009

This article is available from: http://www.microbialcellfactories.com/content/8///52

(C) 2009 Nangia et al; licensee BioMed Central Ltd.

This is an Open Access article distributed under the terms of the Creative Commons Attribution License (http://creativecommons.org/licenses/by/2.0), which permits unrestricted use, distribution, and reproduction in any medium, provided the original work is properly cited.

\section{Retraction}

This article [1] was submitted to Microbial Cell Factories at the same time as a very similar article [2] was submitted to Applied Physics Letters, subsequently published in June 2009. The two articles were produced from the same data and contained extensive overlap including duplication of figures. As such the authors would like to retract the Microbial Cell Factories article. The authors would like to apologise for any inconvenience this may have caused to the editorial staff and readers.

\section{References}

I. Nangia Y, Wangoo N, Goyal N, Shekhawat G, Suri CR: A novel bacterial isolate Stenotrophomonas maltophilia as living factory for synthesis of gold nanoparticles. Microb Cell Fact 2009, 8:39.

2. Nangia Y, Wangoo N, Sharma S, Wu J-S, Dravid V, Shekhawat GS, Raman Suri C: Facile biosynthesis of phosphate capped gold nanoparticles by a bacterial isolate Stenotrophomonas maltophilia. Applied Physics Letters 2009, 94:23390I. 